\title{
Freshwater ecosystems profit from activated carbon-based wastewater treatment across various levels of biological organisation in a short timeframe
}

\author{
Rita Triebskorn ${ }^{1,4^{*}} \mathbb{D}$, Ludek Blaha ${ }^{5}$, Claudia Gallert ${ }^{6}$, Sabrina Giebner ${ }^{7,8}$, Harald Hetzenauer ${ }^{9}$, Heinz-R. Köhler ${ }^{1}$, \\ Bertram Kuch ${ }^{10}$, Frauke Lüddeke ${ }^{9}$, Jörg Oehlmann ${ }^{7}$, Katharina Peschke ${ }^{1}$, Frank Sacher ${ }^{11}$, Marco Scheurer ${ }^{11}$, \\ Simon Schwarz ${ }^{1,2}$, Paul Thellmann ${ }^{1,3}$, Karl Wurm $^{12}$ and Sabrina Wilhelm ${ }^{1}$
}

\begin{abstract}
Background: Wastewater treatment plants are known as major sources for the release of micropollutants and bacteria into surface waters. To reduce this contaminant and microbial input, new technologies for effluent treatment have become available. The present paper reports the chemical, microbiological, biochemical, and biological effects of upgrading a wastewater treatment plant (WWTP) with a powdered activated carbon stage in the catchment area of the Schussen River, the largest German tributary of Lake Constance. Data were obtained prior to and after the upgrade between 2011 and 2017.

Results: After the upgrading, the release of antibiotic resistant and non-resistant bacteria, micropollutants, and their effect potentials was significantly lower in the effluent. In addition, in the Schussen River downstream of the wastewater treatment plant, reduced concentrations of micropollutants were accompanied by both a significantly improved health of fish and invertebrates, along with a better condition of the macrozoobenthic community.

Conclusions: The present study clearly provides evidence for the causality between a WWTP upgrade by powdered activated carbon and ecosystem improvement and demonstrates the promptness of positive ecological changes in response to such action. The outcome of this study urgently advocates an investment in further wastewater treatment as a basis for decreasing the release of micropollutants and both resistant and non-resistant bacteria into receiving water bodies and, as a consequence, to sustainably protect river ecosystem health and drinking water resources for mankind in the future.
\end{abstract}

Keywords: Wastewater treatment plant upgrade, Micropollutants, Bacteria, Fish and invertebrate health

\section{Background}

The increasing presence of micropollutants and microbes, including resistant bacterial strains, in the water cycle, has increasingly been in the focus of scientific, political, and public interest during the last years [1-7]. Microbial contamination of water became a

\footnotetext{
*Correspondence: rita.triebskorn@uni-tuebingen.de

${ }^{1}$ Animal Physiological Ecology, University of Tübingen, Tübingen, Germany

Full list of author information is available at the end of the article
}

particular public concern when drinking water resources could not be used at all or only to a limited extent, such as after contamination with Legionella sp. [8], or when bathing bans had to be issued after levels of faecal indicator bacteria were exceeded [9]. Recently, worldwide findings of antimicrobial resistance in sewage plant effluents, surface waters, and sediments, against both commonly used antibiotics and last-line antibiotics such as colistin, have caused great concern $[7,10]$. Chemical contamination of water attracted the attention of the public following reports on trace substance residues in drinking water 
resources [11-14] and spectacular effects in aquatic organisms, such as sex or behavioural changes in fish induced by xenohormones or neuroactive substances $[15,16]$. In this context, active ingredients of pesticides and pharmaceuticals, but also compounds in products of everyday life (e.g. cosmetics, phytosanitary products, cleansing agents, artificial sweeteners, coffee, etc.), have become a matter of concern.

At present, there are numerous challenges for maintaining good water quality:

(a) The global abundance of antibiotic resistant bacteria is increasing dramatically [10].

(b) Over 140 million organic and inorganic chemicals are registered worldwide (cas.org) and, among those, 30,000 to 70,000 are in daily use in industrialised countries [17]. It is unknown how many of them reach the water cycle.

(c) The mixture of micropollutants is highly complex and contains mother compounds in the $\mathrm{pg}-\mu \mathrm{g} / \mathrm{L}$ range, plus transformation products of often unknown quality and quantity. The risk posed by such chemical mixtures for aquatic wildlife is far from being understood and most probably underestimated due to monitoring practices regarding only a small portion of selected or priority substances.

(d) The demographic change in developed countries will lead to a further increase in product and drug consumption, which will also result in increased emissions of substances via the wastewater path.

(e) Climate change will increase the frequency and length of low-water periods, with rising chemical and bacterial concentrations in pure surface waters. However, a higher frequency of severe rainfall events is also predicted with future climate change, resulting in an increased volume of raw wastewater released into surface water bodies via storm water overflow basins.

Therefore, a sustainable and preventive management of water resources, integrating actions applied after the entry of pollutants and pathogens into the watercourse ("end of pipe" approaches), but also those at the source (i.e. at the level of producers and consumers of the chemicals), is urgently required, and in accordance with the Water Safety Plans of the World Health Organization [18] and the requirements and goals of the EU Water Framework Directive as described by Brack et al. [19]. Such preventative measures are of heightened importance when considering the uncertainties associated with the fate of resistant bacteria in the environment and the possible risk posed by micropollutants to aquatic wildlife, especially when the formation of (often unknown) transformation products of chemicals and mixture effects is also taken into account.

Being important sites of micropollutant and microbe removal from raw wastewater but also point sources for the release of chemicals and microbes into surface waters, improving the efficiency of wastewater treatment plants (WWTP) by additional cleaning steps has become a research area of priority and also a matter of discussion among political groups during the last decade. Many research projects worldwide have addressed this topic, such as the Swiss project "Strategy Micropoll" [20], or the EU projects "SWITCH" [21] and "Pills" [22]. In addition, the German Federal Ministry of Education and Research (BMBF) launched a funding programme called RiSKWa (Risk management of new pollutants and pathogens in the water cycle) in 2012, which allowed 12 research consortia to investigate the efficiency of advanced wastewater and storm water treatment for the reduction in micropollutants and bacteria release into the water cycle. The core messages of all 12 projects are described and summarised by Track [23].

One of these projects (named SchussenAktivplus) did not only focus on the efficiency of advanced sewage and rainwater treatment technologies regarding the removal of micropollutants and bacteria from effluents, but also investigated the consequences of an additional powdered activated carbon-based treatment step for the receiving water body. The effects of the WWTP upgrade were comprehensively monitored, with a special focus on chemical and microbiological parameters, as well as on ecosystem health. The present paper is a compilation of the results that were gathered by 11 (out of 22) project partners by analysing samples collected between 2011 and 2017 in the catchment area of the Schussen River, the largest German tributary of Lake Constance. The structure and concept of the project have been published by Triebskorn et al. [24], and the final report [25] (in German) is available at https://publikationen.unituebingen.de/xmlui/handle/10900/74316.

\section{Methods \\ Upgraded wastewater treatment plant}

With about 170,000 population equivalents, the WWTP Langwiese, Association for Sewage Treatment (AZV) Mariatal, Germany, represents a large WWTP in a densely populated catchment of an industrialised country. The WWTP was equipped with an activated carbon stage in autumn 2013 and, ever since, 100\% of the sewage has been treated with powdered activated carbon, added after biological treatment and before entering a connected sand filter. During this study, the dosage was $10 \mathrm{mg} \pm 5 \mathrm{mg}$ powdered activated carbon per litre of wastewater. The dosage was adjusted according to the 
need of an $80 \%$ reduction in micropollutants. The location of the WWTP Langwiese in the catchment area of the Schussen River is displayed in Fig. 1.

\section{Investigated rivers and catchments}

Field data were collected along the Schussen River at 2 sites upstream (S0, S1) and 3 sites downstream (S2, S3, S6) of the upgraded WWTP and at 2 sites (S4 and S5) along the Argen River (a nearby less polluted tributary of Lake Constance) as a reference river (Fig. 1). Sites S4 and S5 served as control sites for annual or seasonal confounding factors such as temperature. Site S0 was located upstream and S1 downstream of a large storm water overflow basin (SOB) [25-27]. No structural changes of the river beds were realised in the sampling area during the project.

With about 200,000 inhabitants and a settlement area of $11 \%$, the catchment area of the Schussen is fairly densely populated. A total of $25 \%$ of the catchment area is covered by forests, $30 \%$ is used for arable farming, and a further $33 \%$ is either covered by grassland or in use for special crops (fruits, hops, wine). The urban drainage takes place predominantly via mixed channel systems. The wastewater in the Schussen catchment is treated by 20 municipal sewage treatment plants. These include, in addition to the upgraded WWTP Langwiese with 170,000 population equivalents (size class 5), five WWTPs of size class 4 (>10,000 population equivalents). Seventeen of these WWTPs (four larger ones) are located upstream of the upgraded WWTP. The upgraded WWTP cleans about $50 \%$ of the entire catchment wastewater, which is mostly of domestic origin. However, industrial wastewater, especially that of a paper mill at Mochenwangen, which was closed in 2015, also played a role in the past. In addition to the WWTPs, more than 100 storm water overflow basins are connected to the Schussen [28].

\section{Field sampling for chemical and microbiological analyses as well as for effect-oriented biotests and biomarker studies}

Sampling of water

For chemical analyses and biotests, 24-h composite samples of the WWTP's effluent were taken 6 times prior to

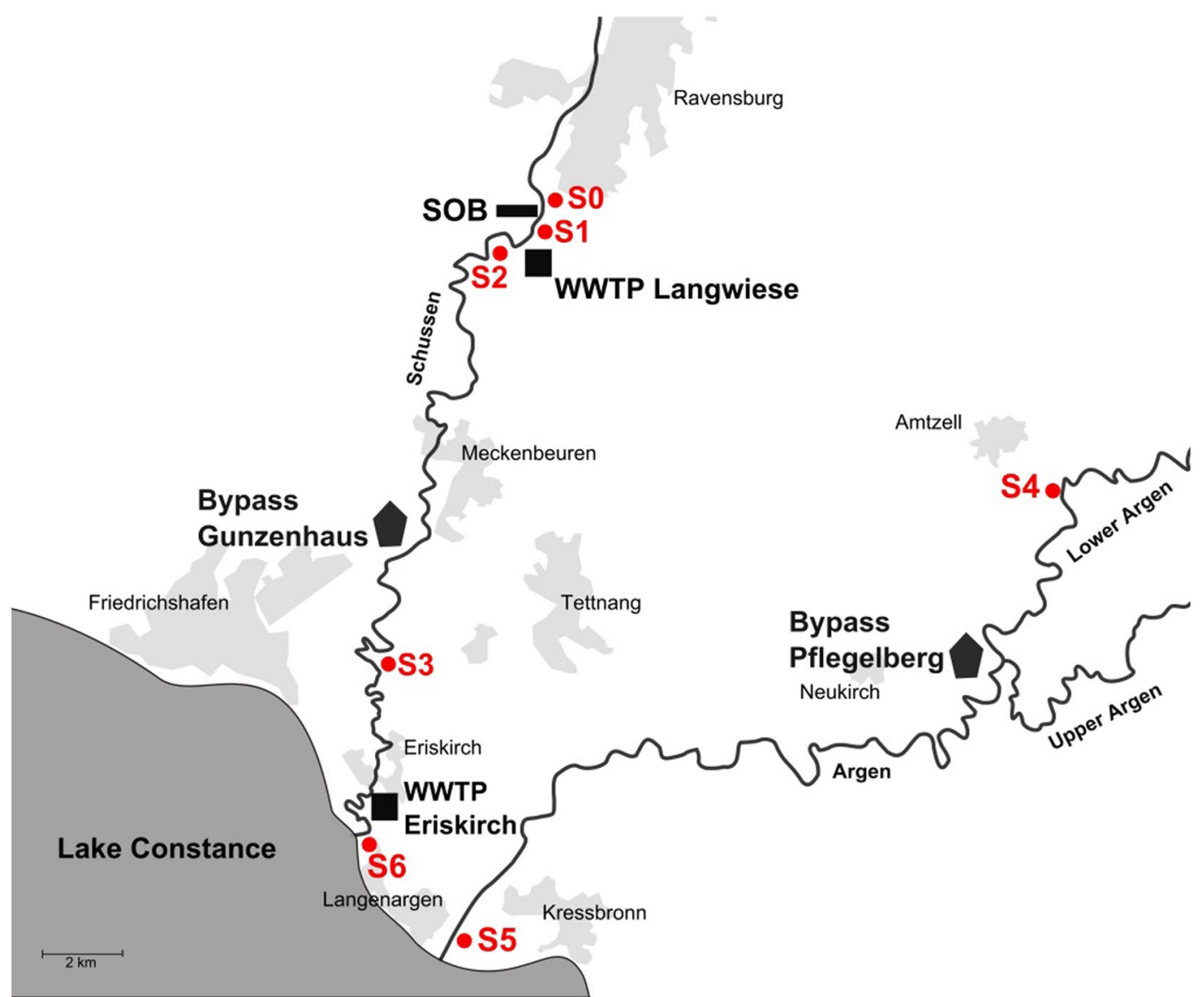

Fig. 1 Location of the WWTP Langwiese, the field sampling sites, and the bypass stations. The map is based on OpenStreetMap. Map data, oOpenStreetMap contributors, http://opendatacommons.org/licenses/dbcl/1.0/.e 
and 8 times after implementing the additional treatment step. The field sites S0, S1, S3, S4, S5, and S6 (Fig. 1) were sampled 8 times between 2010 and 2016, 4 times prior, and 4 times after the upgrade (grab samples). Water samples were taken in autoclaved brown glass bottles and were either stored at max. $4{ }^{\circ} \mathrm{C}$ or, if analyses within one week after sampling were not feasible, frozen. Detailed information on the sampling procedures is given by Thellmann et al. [29].

For the analyses of bacteria, 24-h composite samples of the effluent were taken 5 times prior to and 8 times after the WWTP upgrade. These samples were also taken in autoclaved brown glass bottles and stored at max. $4{ }^{\circ} \mathrm{C}$ until being further processed the following day. In three samples prior to and three samples after the WWTP implementation, resistant bacteria were analysed.

\section{Sampling of gammarids, feral fish, and macrozoobenthos}

For biomarker analyses in gammarids [27], Gammarus roeseli and Gammarus pulex were collected at sampling sites S0, S1, S3 (Schussen River), and S5 (Argen River) on the same day as the grab samples for chemical and microbiological analyses were taken. For biomarker studies in feral fish [30], chub (Leuciscus cephalus) and spirlin (Alburnoides bipunctatus) were caught by electrofishing at sampling sites S0, S1, S3 (Schussen River), and S4 (Argen River). We did not investigate feral fish from site S2, which was very close to the effluent, since, according to own results in the past, both selected species do not permanently reside downstream of the WWTP, but also move upstream of it. The macrozoobenthic community was investigated during the same time span in spring and autumn at sites S0, S1, S2, S3, and S4 [27].

\section{Exposure of fish in the field Bypass exposure}

More detailed information on exposure conditions and procedure of fish sampling are provided by Henneberg et al. [31], Maier et al. [32], and Wilhelm et al. [30]. Before and after the WWTP upgrade, eggs of rainbow trout (Oncorhynchus mykiss) and brown trout (Salmo trutta f. fario), as well as juvenile fish of both species, were exposed in a bypass mesocosm connected to the Schussen River downstream of the WWTP (Bypass Gunzenhaus), and as a reference, in a bypass system flown through by the water of the Argen River (Bypass Pflegelberg). The exact locations are shown in Fig. 1. Exposure took place in $250 \mathrm{~L}$ aquaria in which stainless steel sieves were included to keep the eggs. Exposure lasted for about 4 months (eggs and hatched fish), and 6-8 weeks for juvenile fish. Both fish eggs and juvenile fish were provided by the fish farm Lohmühle (Alpirsbach, Germany), a breeding facility which is subjected to regular controls and rated as category I, disease-free [33]. Since the breeder supplies brown trout for fishery restocking campaigns in German streams, the chosen variety of brown trout used in this study is considered robust and close to feral forms.

\section{Cage exposure}

Cage exposure experiments are described in detail by Henneberg et al. [31] and Wilhelm et al. [30]. Prior and subsequent to the WWTP upgrade, 1-year-old rainbow trout (Oncorhynchus mykiss) were exposed in two cages $(60 \times 100 \times 50 \mathrm{~cm}$, described in detail by Vincze et al. [34]) for 7 weeks, both upstream and downstream of the WWTP. In each cage, 20 fish were exposed either $50 \mathrm{~m}$ upstream or directly downstream of the effluent, the latter receiving a mixture of approximately $50 \%$ effluent and $50 \%$ river water. Fish were fed every 2 days with equal amounts of food provided by the hatchery. Rainbow trout serving as reference fish were dissected directly at the fish hatchery at the end of the exposure.

\section{Chemical analyses}

Further information on the applied methods for chemical analyses can be found in Scheurer et al. [35] and Triebskorn [25].

A total of 145 micropollutants were analysed in water, sediment, and tissue samples. Out of these, 17 chemicals with a constant discharge in recipient waters were defined as indicator compounds for additional analyses. These included: carbamazepine, 10,11-dihydro10,11-dihydroxycarbamazepine, diclofenac, acesulfame, $\mathrm{N}$-acetyl-4-aminoantipyrine, $\mathrm{N}$-formyl-4-aminoantipyrine, perfluorobutanoate (PFBA), perfluorooctanoate (PFOA), perfluorooctanesulfonate (PFOS), $1 \mathrm{H}$-benzotriazole, 4-methylbenzotriazole, 5-methylbenzotriazole, sulfamethoxazole, tris(2-chloropropyl)phosphate, iomeprol, iopamidol, and iopromide. To control the upgrading measures with sufficiently high temporal resolution, these indicator compounds were measured not only in the 24-h composite samples of the effluent and the surface water samples taken at the respective field sites, but also in 65 additional samples of the WWTP effluent. The effect of the upgrading measure on the average release of micropollutants into the Schussen was estimated. This was done by taking the amount of the annually treated wastewater and the average concentrations prior and after upgrading of the respective micropollutants into account. Micropollutants, such as pharmaceuticals, were analysed by gas or liquid chromatography coupled to mass spectrometry. The analytical techniques used for solid samples were similar to those used for water samples, but required sample preparation that efficiently removed co-extracted matrix compounds. The analyses of fish 
tissue and sediment samples focussed on non-polar compounds (e.g. polycyclic aromatic hydrocarbons, perfluorinated and polyfluorinated alkyl substances), which were more likely to accumulate in these compartments. In addition to micropollutant analyses, physicochemical and hydrochemical water parameters including temperature, $\mathrm{pH}$, electrical conductivity, and dissolved oxygen were regularly recorded, either during the sampling events or continuously by data loggers (in the bypass systems) for temperature, $\mathrm{pH}$, electrical conductivity, and dissolved oxygen.

\section{Quantification and antibiotic susceptibility testing of faecal indicator bacteria and staphylococci}

Detailed information on the microbiological analyses can be found in Scheurer et al. [35] and Heß et al. [36].

Briefly, concentrations of faecal bacteria [Escherichia coli (E. coli), staphylococci, and enterococci] were analysed in effluent samples as well as in surface water and sediments of the field sites. Prior to the WWTP upgrade, 5 samples were analysed for E. coli and enterococci and 3 samples for staphylococci. After the WWTP upgrade, 8 water samples were analysed for $E$. coli and enterococci and 3 samples for staphylococci. Antibiotic resistant $E$. coli and enterococci were determined in randomly selected isolates (10 each) taken from three sampling campaigns prior to and three campaigns after the WWTP upgrade.

In order to directly obtain E. coli isolates for further antimicrobial susceptibility testing, appropriately diluted samples were plated on Escherichia Coli Direct (ECD) agar. In agreement with ISO EN 9508-32, colonies with positive glucuronidase and indole reaction were counted as E. coli. Concentrations of intestinal enterococci were determined according to ISO EN 7899-2 by counting colonies with positive aesculin reaction on Slanetz-Bartley agar. Chapman-Stone agar supplemented with $0.05 \mathrm{~g} / \mathrm{L}$ natrium azide was used to quantify staphylococci in treated sewage and surface waters. The obtained isolates were identified at the species level by the use of physiological tests in MicronautStaph $^{\circledR}$-microtiter plates.

From 3 samples taken prior to and 3 samples taken after implementation of the WWTP upgrade, randomly selected isolates of staphylococci, intestinal enterococci, and $E$. coli (10 each) were tested for their antibiotic susceptibility according to DIN 58,940. Susceptibility of $E$. coli isolates was tested against ampicillin, cefotaxime, ciprofloxacin, and sulfamethoxazole/trimethoprim. Intestinal enterococci were tested for their susceptibility to ampicillin, erythromycin, chloramphenicol, ciprofloxacin, and vancomycin.

\section{Biotests}

With the aim of detecting effect potentials in environmental samples (WWTP effluent, surface water, and sediment), a series of in vitro and in vivo biotests were conducted (Table 1). In the present paper, data for oestrogenicity, anti-oestrogenicity, androgenicity, dioxin-like toxicity, and zebrafish embryo toxicity will be presented.

\section{Biomarkers and health indicators}

In order to assess the health status of either actively exposed or feral fish and of gammarids, series of biomarkers were applied. In fish, histopathological effects and stress proteins of the hsp70 family were analysed in livers, gills, and kidneys according to Maier et al. [32] and Wilhelm et al. [30]. In addition, the glycogen content of the livers was determined following methods described by Wilhelm et al. [30]. Genotoxic effects were assessed by means of the micronucleus test with red blood cells, and biotransformation activity in the liver was measured with the EROD assay (both methods described by Maier et al. $[26,32])$. With the aim of detecting possible neurotoxic effects in fish, the activities of acetylcholinesterase and carboxyl esterase were determined using the methods of Rault et al. [50] and Chanda et al. [51]. As a biomarker for oestrogenic effects, the vitellogenin content in blood samples of juvenile fish and in whole body homogenates of fish larvae was analysed according to Henneberg and Triebskorn [31]. The embryonic development of brown trout and rainbow trout was studied by means of a fish early life stage test (ELS) according to OECD 210 (described by Henneberg et al. [43], Maier et al. [32], and Luckenbach et al. [52]). In gammarids, sex ratio, fecundity, and stress proteins (hsp70 family) were investigated (methods described by Peschke et al. [27]). The macrozoobenthic community was sampled according to the multi-habitat sampling method. Compliant with the EU Water Framework Directive [53], the saprobic index, the number of taxa, and the number of sensitive taxa were determined (methods described by Peschke et al. [27]).

\section{Statistics}

The respective methods used for the statistical analyses of method-specific data have been described elsewhere $[25,27,30,32,35,37,43,47,54]$. For the overall statistical analyses on which Figs. 2, 7, and 9 are based, multivariate data analyses were carried out using the program Canoco 4.5. In a first step, a principal component analysis (PCA) was conducted to identify correlations between the investigated endpoints and reduce the dataset to a meaningful selection. The second step was a redundancy analysis (RDA) performed to identify correlations between the measured endpoints and environmental 
Table 1 Biotests used to detect effect potentials in environmental samples (effluent, surface water, and sediment) in the project SchussenAktivplus

\begin{tabular}{lll}
\hline Testing for & Biotest used & According to \\
\hline Genotoxicity & Ames-fluctuation test & ISO 11350 guideline, described in detail by Giebner et al. \\
& SOS Chromotest & White et al. [38] \\
& Reporter gene assay with H4IIE-luc-cells & Garrison et al. [39], described in detail by Maier et al. [32] \\
Dioxin-like toxicity & Yeast Dioxin Screen & Stalter et al. [40] \\
& Y(A)ES & Stalter et al. [40], described in detail by Giebner et al. [37] \\
(Anti-) Oestrogenicity & E-Screen & Lange et al. [41] \\
& Reporter gene assay with HeLA cells & US EPA [42], described in detail by Henneberg et al. [43] \\
& Y(A)AS & Stalter et al. [40], \\
(Anti-) Androgenicity & described in detail by Giebner et al. [37] \\
& Reporter gene assay with MDA-kb2-cells & Wilson et al. [44] \\
& Lemna minor growth inhibition test & OECD 221 [45] \\
Phytotoxicity & Fish embryo acute toxicity test (FET) with Danio rerio & OECD 236 [46], described in detail by Thellmann et al. \\
Embryo- and developmental toxicity & [47] \\
& Sediment and water toxicity test with Lumbriculus & OECD 225 [48] \\
Effects on reproduction & variegatus & OECD 242 [49], described in detail by Giebner et al. [37] \\
& Potamopyrgus antipodarum reproduction test & and Henneberg et al. [43]
\end{tabular}

variables. For the analyses of chemical data (Fig. 2) and biotest results (Fig. 7), the different treatment steps and the sampling year were used as environmental variables. In cases where substance concentration was below the limit of quantification, the respective substance was excluded from statistical analyses. For the analyses of the biomarker results of exposed rainbow trout (Fig. 9), sampling site and sampling year were used as environmental variables. If necessary, models were reduced by specific treatment steps or sampling sites, respectively, in order to get a more detailed analysis of the remaining parameters. Further details can be obtained from Triebskorn [25].

\section{Results}

\section{Chemical analyses}

A detailed description of the following RDA results regarding chemical analyses can also be found in Triebskorn [25]. The first analysis of all analytical data available for the effluent of the WWTP Langwiese revealed a high number of highly correlated variables. In particular, the sum parameter "specific UV absorbance at $254 \mathrm{~nm}$ " (SAK254) showed a strong correlation with numerous chemicals. Therefore, this parameter was used as a representative variable in the following analyses. Overall, the RDA showed a visible grouping according to the parameters "sampling year" and "cleaning stage" (Fig. 2). In particular, data for the "old" effluent prior to the upgrade (representing the years prior to the WWTP upgrade 2012-early 2014) and those for the "new" effluent after

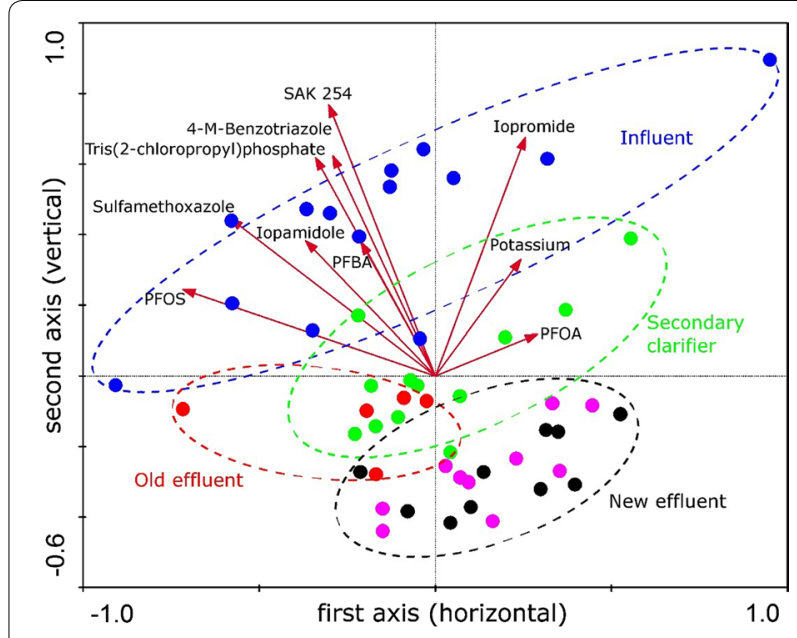

Fig. 2 RDA for chemical analyses of water samples from different cleaning stages at the WWTP Langwiese. Samples were collected between 2012 and 2016. First (horizontal) and second (vertical) axes are shown. The effluent after primary treatment is represented by blue dots (influent), the secondary clarifier by green dots, the "old" effluent with a flocculation/sand filter (without activated carbon) by red dots, the activated carbon stage by violet dots, and the "new" effluent with activated carbon stage and sand filter by black dots. Red arrows depict the investigated endpoints. The length of the arrow indicates the magnitude of effect, and the distance between the arrow and axes indicates their strength of correlation. SAK254: spectral absorption coefficient at $254 \mathrm{~nm}$, a sum parameter giving information about the organic load in water samples. The first axis is primarily determined by the sampling year. Data for 2012 to early 2014 (prior to the WWTP upgrade) are shown on the left side of the figure, those for data from late 2014-2016 (after the WWTP upgrade) on the right side. The second axis allows for distinction between the different treatment stages 
the upgrade of the WWTP (late 2014-2016) were clearly separated from each other, with much higher chemical loads measured prior to the installation of the additional powdered activated carbon stage.

In total, $55.4 \%$ of the variation could be explained by the environmental variables. The first axis was primarily determined by the sampling year and accounts for $35.6 \%$ of the total variation $(64.2 \%$ of the explainable variation). The second axis was largely determined by the purification stages and, together with the first axis, accounts for $52.4 \%$ of the variation $(94.5 \%$ of the explainable variation). The third axis (not depicted) separated the secondary clarifier from the other purification stages and explained, cumulatively with the first and second axes, $55.1 \%$ of the variation $(99.3 \%$ of the explainable variation).

Chemical analyses of the surface water samples also revealed a significant reduction for a great portion of detected chemicals in samples taken downstream of the WWTP (sites S3 and S6) following the installation of the additional powdered activated carbon stage (Fig. 3) Selected data have already been published by Wilhelm et al. [30].

Calculations on annual releases of micropollutants into the Schussen River via the WWTP Langwiese based on extrapolations from our measurements showed that, due to the upgrade, on average $50 \%$ less chemicals were released into the river compared to the situation prior to the installation of the powdered activated carbon stage (Fig. 4a, b).

Concentrations of both diclofenac [30] and PFOS analysed in effluent, surface water downstream of the WWTP, and in muscle tissue of trout actively exposed in the Schussen River downstream of the WWTP were markedly reduced after the installation of the powdered activated carbon stage (Fig. 5a, b).

\section{Analyses of selected faecal bacteria, staphylococci, and antibiotic resistance behaviour}

Prior to the WWTP upgrade, the effluent contained $6.5 \mathrm{E}+03 \mathrm{E}$. coli colony-forming units (CFU)/100 mL, $2.1 \mathrm{E}+03$ enterococci $\mathrm{CFU} / 100 \mathrm{~mL}$, and $3.8 \mathrm{E}+02$ staphylococci CFU/100 mL (mean values). After the upgrade, 3.4 $\mathrm{E}+03$ E. coli $\mathrm{CFU} / 100 \mathrm{~mL}, 2.5 \mathrm{E}+02$ enterococci CFU/100 mL, and $1.2 \mathrm{E}+1$ staphylococci CFU/100 mL were found (Fig. 6). Thus, the upgrade reduced the bacterial concentration in the effluent by between 0.28 and 1.5 logarithmic units. In comparison with the secondary clarification step, concentrations of E. coli and enterococci were reduced by even more than 2 logarithmic units (data not shown). In the case of enterococci, the concentration was significantly lower after implementing the activated carbon treatment step $(p$ value $=0.003$;

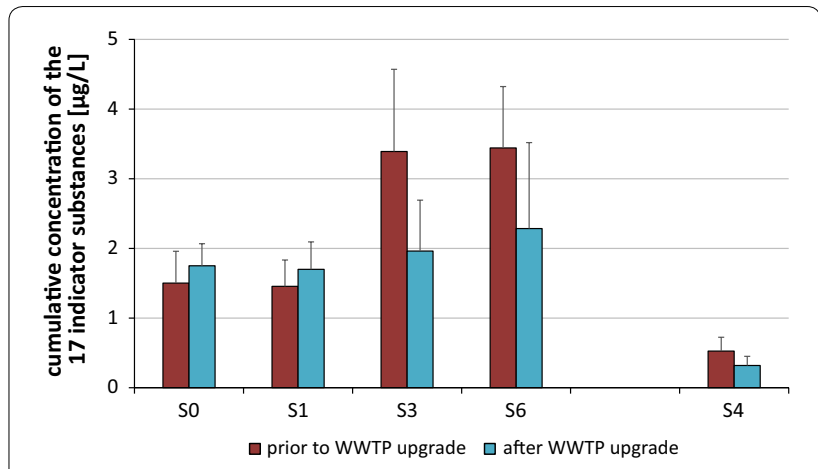

Fig. 3 Cumulative concentrations of 17 indicator substances in surface water of the Schussen River. Mean values and standard deviations are shown. The 17 indicator substances are listed individually in the Methods section. Samples were collected upstream $(\mathrm{SO}, \mathrm{S} 1)$ and downstream $(\mathrm{S3}, \mathrm{S6})$ of the WWTP Langwiese and in surface water of the Argen River (S4) prior to (red) and after (blue) the WWTP upgrade

bilateral $t$-test) and was even below the upper limit for adequate bathing water quality.

Due to limited samples analysed for antibiotic resistance (3 samples prior to and 3 samples after the WWTP upgrade), we refrained from statistical analyses of these data. Overall, however, the WWTP upgrade resulted in a reduction in antibiotic resistant $E$. coli and enterococci by 0.7 to 1.1 logarithmic units (Fig. 6, hatched bars).

\section{Biotests}

\section{Water samples taken at the WWTP Langwiese}

The detailed results obtained in the biotests have already been published [25, 26, 29, 31, 32, 43]. Initial statistical analyses of biotest data revealed a strong influence of the primary effluent on the dataset, which may have masked possible differences between the subsequent treatment steps. Therefore, further analyses were conducted with a data subset after exclusion of the primary effluent data. Overall, the RDA of the biotest results showed a clear separation of data by the factors "sampling year," which primarily determined the first axis, and "cleaning stage" (Fig. 7). The first axis explained $62 \%$ of the total variation $(76 \%$ of the explainable variation). The second axis allowed a distinction between the effluent of the secondary clarifier and the following treatment steps. Thus, water samples taken after the secondary clarifier generally elicited the strongest reactions, in particular those indicating oestrogenic (E-Screen) and embryotoxic (mortality) potentials. Together with the first axis, the second axis explained $77.3 \%$ of the variation ( $94.7 \%$ of the explainable variation). The third axis further separated the effluents of the sand filter and the activated carbon stage. Hence, samples of the "old" effluent without activated carbon treatment showed a 
(a)

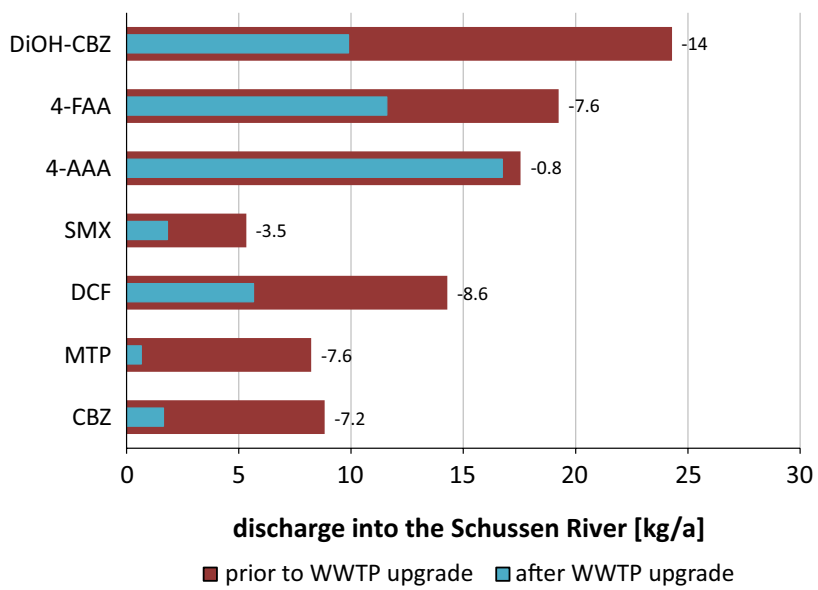

(b)

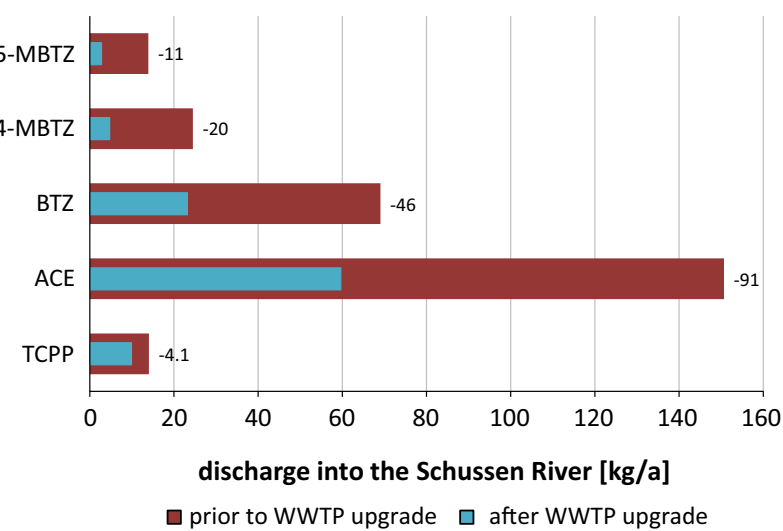

Fig. 4 Extrapolated discharge (kg/a) of a pharmaceuticals and $\mathbf{b}$ selected micropollutants by the WWTP Langwiese. Analyses were conducted with surface water samples taken from the Schussen River prior to (red) and after (blue) the WWTP upgrade. Numbers next to columns represent differences before and after the upgrade (negative values represent reduction in discharge after the upgrade). Left: 10,11-dihydro-10,11-dihydr oxycarbamazepine (DiOH-CBZ), 4-formylaminoantipyrine (4-FAA), 4-acetaminoantipyrine (4-AAA), sulfomethoxazole (SMX), diclofenac (DCF), metoprolol (MTP), and carbamazepine (CBZ); right: 4- and 5-methylbenzotriazole (4- and 5-MBTZ), 1H-benzotriazole (BTZ), acesulfame (ACE), and tris(2-chloropropyl)phosphate (TCPP)

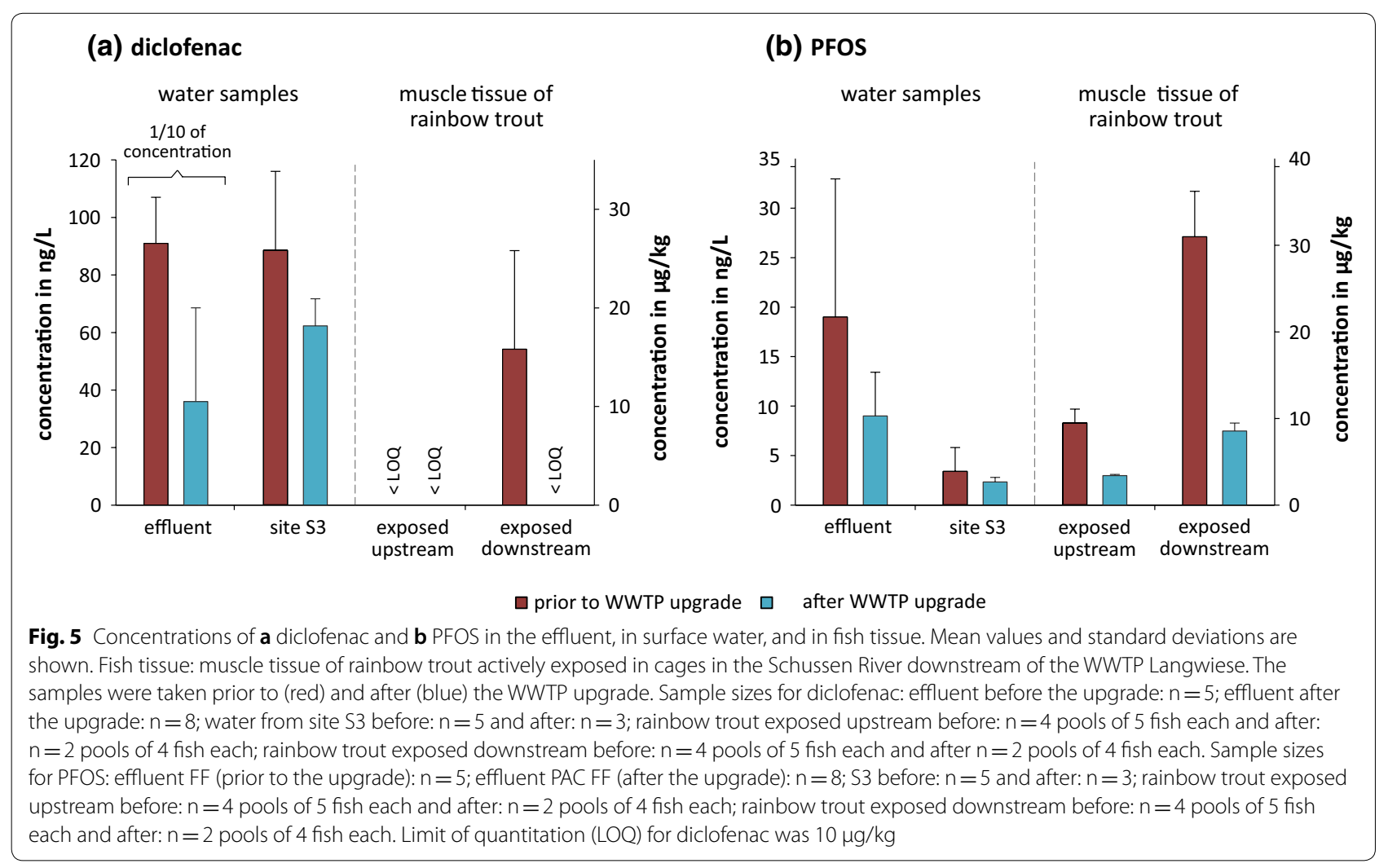




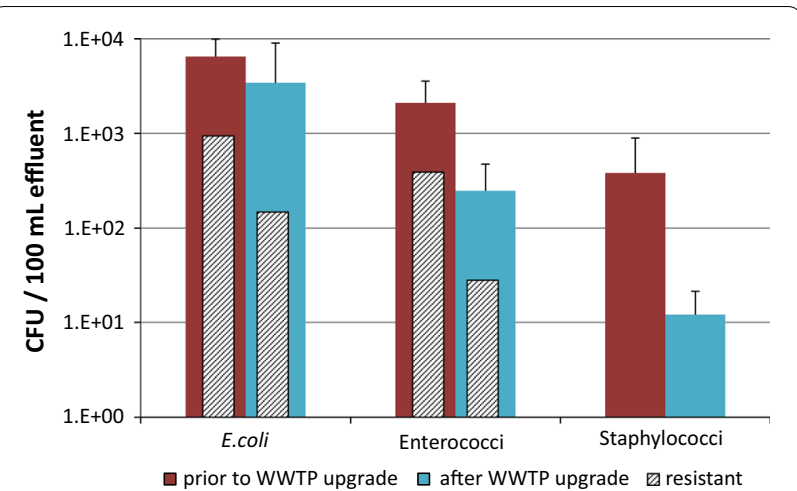

Fig. 6 Concentrations (colony-forming units/100 mL) of E. coli, enterococci, and staphylococci in the WWTP effluent. Water samples were taken prior to (red) and after (blue) the upgrade of the WWTP Langwiese. Hatched bars represent concentrations of antibiotic resistant bacteria. Mean values and standard deviations are shown (standard deviations for total number of bacteria only, and not for antibiotic resistant bacteria). Sample sizes for total number of bacteria: prior to upgrade: $n=5$ for E. coli and enterococci and $n=3$ for staphylococci; after upgrade: $n=8$ for E. coli and enterococci and $\mathrm{n}=3$ for staphylococci; antibiotic resistant $E$. coli and enterococci were determined in randomly selected isolates (10 each) of samples taken 3 times prior to and 3 times after the WWTP upgrade strong positive correlation with biotests indicating androgenic potentials (YAS). After installation of the additional treatment stage, a pronounced reduction in distinct effect potentials could be detected in contrast to the other investigated effluents. In particular, the hatching rate of Danio rerio in the FET [55] was higher, indicating a reduction in embryotoxic substances by the additional treatment. However, treatment with powdered activated carbon also led to an increase in anti-oestrogenic potentials (YAES) [25].

\section{Water samples taken at field sites}

Toxic and endocrine potentials in surface water samples taken downstream of the WWTP were markedly reduced after the WWTP upgrade (Fig. 8). In comparison with the reference site S0 (upstream of the WWTP), oestrogenic, androgenic, and dioxin-like potentials were much lower, and the mortality as well as the developmental delay of Danio rerio embryos was decreased (original data in parts published by Maier et al. [26] and Thellmann et al. [29]). However, as in the biotests conducted with different effluent samples prior to and after the WWTP upgrade, we did not find a significant reduction in anti-oestrogenicity downstream the WWTP after the
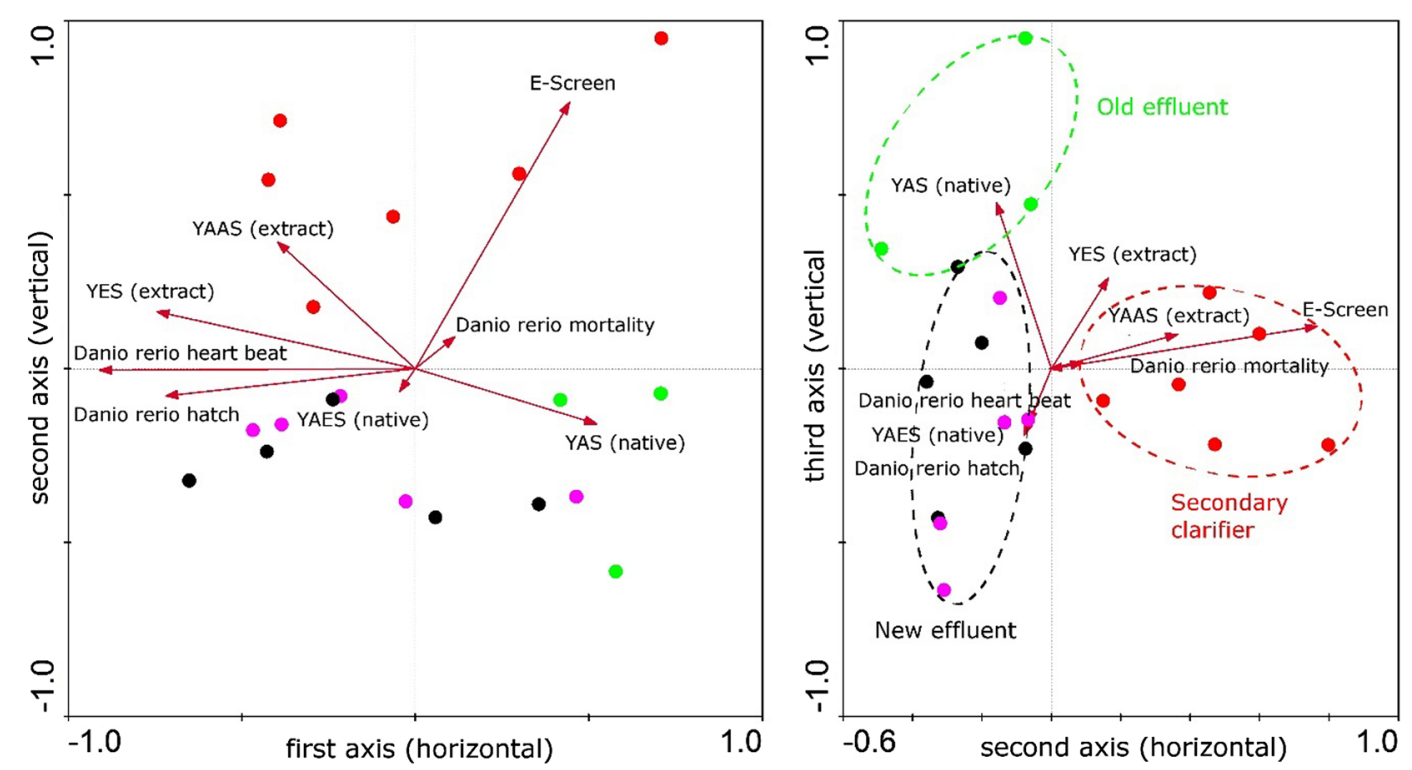

Fig. 7 RDA for biotests with water samples taken at different cleaning stages at the WWTP Langwiese. Tests conducted with effluent samples after primary treatment were excluded. Left: first (horizontal) and second (vertical) axes; right: second (horizontal) and third (vertical) axes. The results for the "old" effluent with sand filter only (without activated carbon) are represented by green dots, the results for analyses with water samples taken after the secondary clarifier are shown in red, and analyses with samples taken after treatment with activated carbon plus sand filtration ("new" effluent) are shown in black and pink (black: only activated carbon; pink both activated carbon plus sand filter). Red arrows depict the investigated endpoints. The length of the arrow indicates the magnitude of effect, and the distance between the arrow and axes indicates their strength of correlation. Y(A)ES: Yeast (anti-) oestrogen screen; Y(A)AS: Yeast (anti-) androgen screen. The first axis is primarily determined by the sampling year. Data for 2012 to early 2014 (prior to the WWTP upgrade) are shown on the right side of the left figure, those for data from late 2014-2016 (after the WWTP upgrade) on the left side. The second axis allowed for a distinction between the effluent of the secondary clarifier and the following treatment steps. The third axis separated the effluents of the sand filter and the additional activated carbon stage 


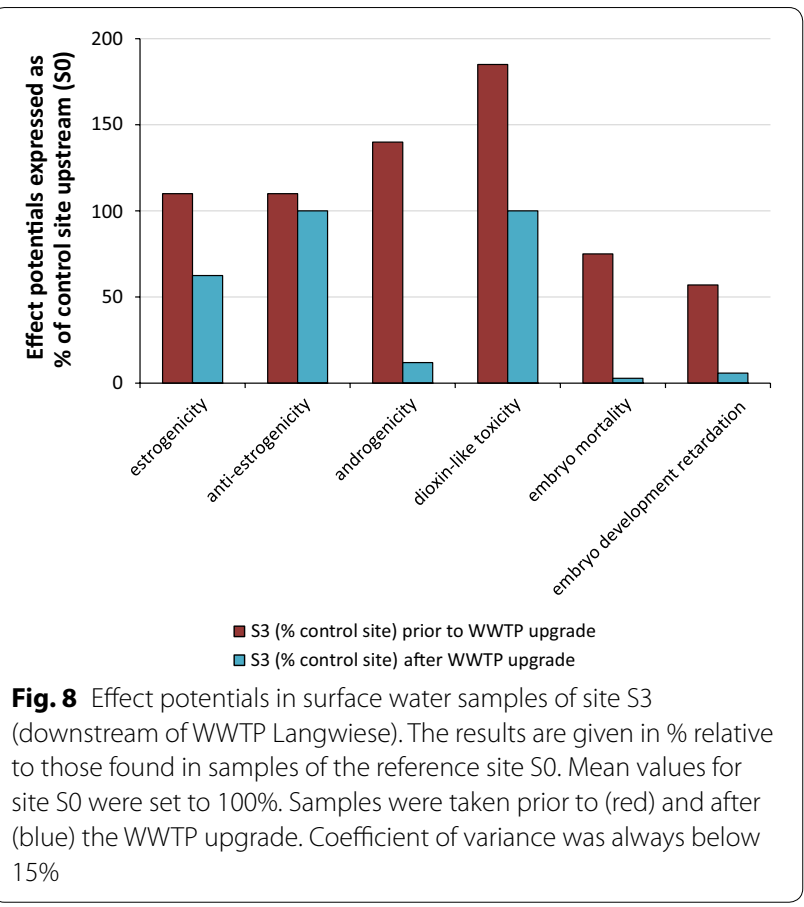

upgrade. Data for genotoxicity, phytotoxicity, and impact on reproduction were either very low already prior to the WWTP upgrade or showed a high degree of variation throughout all sampling campaigns.

\section{Biomarkers and health indicators Fish health}

The RDA results for all biomarker studies in rainbow trout exposed in cages at the WWTP Langwiese are presented in Fig. 9. The first axis accounts for $30 \%$ of the total variation (92.2\% of the explainable variation) and was primarily linked to the factor "sampling year." On the basis of the second axis, we could distinguish between different cage positions, i.e. upstream and downstream of the effluent. Together, the first and second axes explained $32.5 \%$ of the variation $(100 \%$ of the explainable variation). Prior to the WWTP upgrade, there was a clear separation of data obtained for fish exposed either in cages upstream or downstream of the WWTP. After the installation of the additional treatment with powdered activated carbon, these differences were no longer visible. In particular, a pronounced reduction in deleterious histopathological alterations in different organs [30], as well as a reduction in genotoxic (micronuclei) and dioxin-like (EROD activity) effects [26, 32, 56], could be detected in fish exposed downstream of the effluent after the WWTP upgrade. Very similar observations were made in rainbow trout and brown trout exposed at the bypass station and in feral fish caught

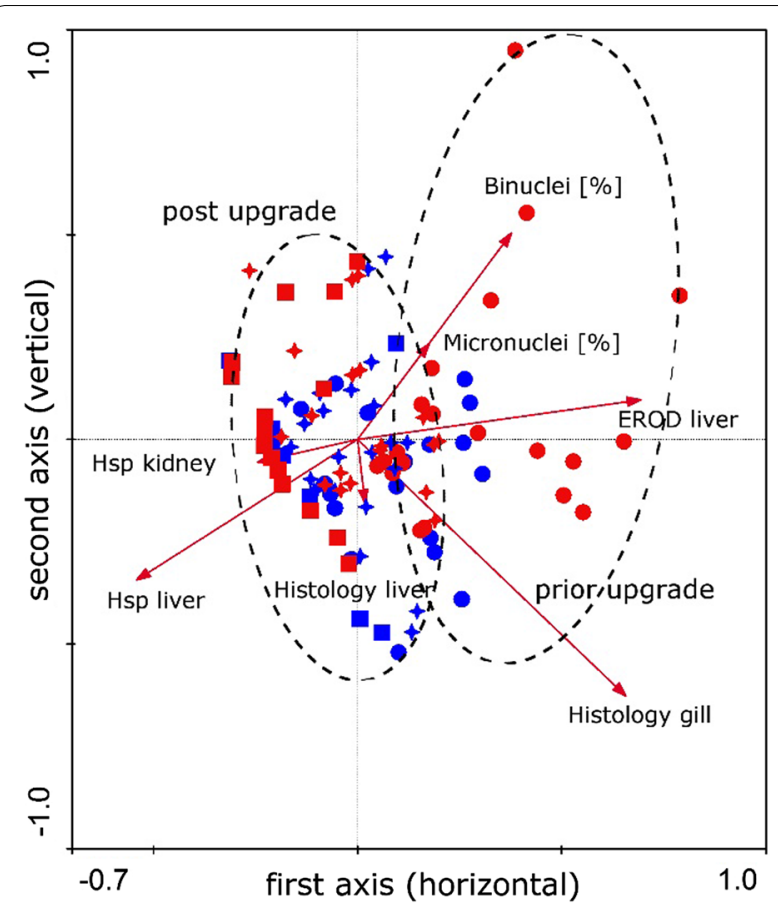

Fig. 9 RDA results of biomarker studies in cage-exposed rainbow trout. Samples were taken before (dots: winter 2012/2013) and after (asterisks: winter 2013/2014; squares: winter 2014/2015) the WWTP upgrade. Data for fish exposed upstream of the effluent are displayed in blue, and the results for individuals exposed downstream of the effluent are shown in red. Red arrows depict the investigated endpoints. The length of the arrow indicates the magnitude of effect, and the distance between the arrow and axes indicates their strength of correlation. EROD liver: hepatic EROD activity; Hsp: heat shock protein level measured in various organs; histology: degree of histopathological alterations detected in various organs; Micronuclei and binuclei: percentage of erythrocytes with micronuclei and binuclei. The first axis was primarily determined by the factor "sampling year", i.e. prior to and after the upgrade. The second axis was linked to the different cage positions, i.e. upstream and downstream of the effluent

downstream of the WWTP. In addition, much higher levels of glycogen storage were found in rainbow trout exposed at the Schussen bypass station after the WWTP upgrade than before [30], which might be explained by the fact that fish need to allocate less energy for, e.g. biotransformation of pollutants. There was no indication of the presence of neurotoxic substances in the river, irrespective of the sampling date [25]. Furthermore, there was no vitellogenin induction in male fish, neither before nor after the WWTP upgrade, indicating that fish were not exposed to a considerable level of oestrogen-like substances. However, vitellogenin levels in blood of female brown trout exposed at the Schussen bypass station were significantly reduced after the WWTP upgrade [31] which might have been due to the increase in anti-oestrogenicity as indicated by the YAES. 
There was a significant increase in the hatching rate of rainbow and brown trout exposed at the bypass stations after the upgrade, although this was also observed at the Argen bypass station (reference site) [25].

\section{Effects in gammarids}

A reduction in adverse effects after the installation of the additional treatment step was also observed in gammarids (details published by Peschke et al. [54, 57]). Prior to the installation of the additional treatment, a significantly reduced fecundity index of gammarids living at site S3 could be observed, whereas after the WWTP upgrade, fecundity indices at sites S0 and S3 were similar. Furthermore, the shift in sex ratio towards females, which was detected in summer samplings before the installation of the powdered activated carbon stage, disappeared after the upgrade.

\section{Macrozoobenthos}

Saprobic index The results are described in more detail by Peschke et al. [54]. Prior to the WWTP upgrade, a pronounced increase in the saprobic index could be detected at site $\mathrm{S} 2$ downstream of the effluent compared to the reference site S0 (Fig. 10). After the upgrade, a reduction in this difference could be observed, due to a higher saprobity at site S0 and a lower saprobic index at site S2. The lower saprobic index at site S2 was mainly caused by a quantitative increase in species sensitive to pollution and by a quantitative decline in several saprophilous species (e.g. Erpobdella octoculata, Tubifex spp.).

Number of taxa and sensitive taxa The following results are described in more detail by Peschke et al. [54]. Compared to reference sites upstream of the WWTP, a lower number of macrozoobenthic taxa were detected at site S2 prior to the WWTP upgrade (Fig. 11). In addition, the abundance of individuals was much lower compared to sites S0 and S1. After the upgrade, an increase in the number of macrozoobenthic species and, in particular, an increase in the number of species that are classified as "sensitive" could be found downstream of the effluent, such as Perla abdominalis, Perla marginata, Protonemura sp., and Leuctra fusca. These results were corroborated by analysis of similarities (ANOSIM) for the entire community and for the sensitive taxa dataset. The comparison of the community structure prior vs. subsequent to the upgrade of the WWTP showed significant differences indicating a positive effect of the WWTP upgrade [54].

\section{Discussion}

This paper presents the integrative analysis of a dataset comprising about 93,000 database entries as the final outcome of a comprehensive and multidisciplinary project.

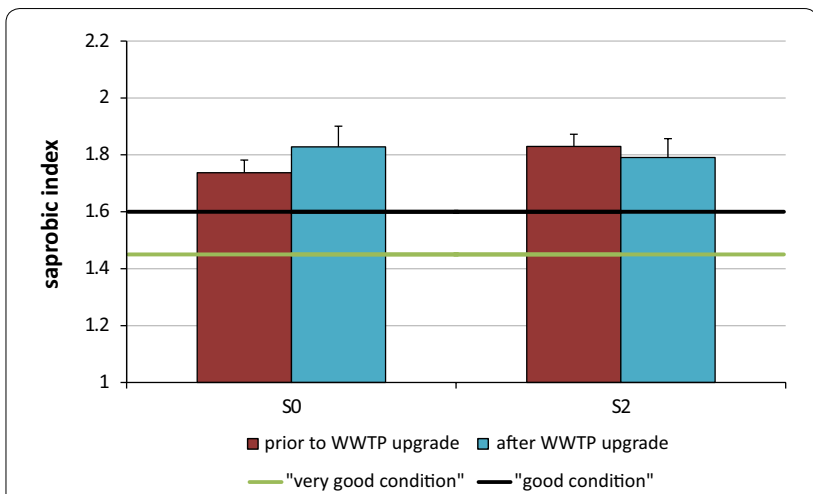

Fig. 10 Saprobic index at two sites in the Schussen River before and after the WWTP upgrade. Mean values and standard deviations are shown. Samples were taken two times per year in spring and autumn before (red; spring and autumn 2011, 2012, 2013) and after (blue; spring and autumn 2014, 2015, 2016) the WWTP upgrade. S0: reference site upstream of the effluent; $\$ 2$ : directly downstream of the effluent. Classification thresholds for "very good condition" (green line) and "good condition" (black line) according to the Water Framework Directive (stream type 3.2)

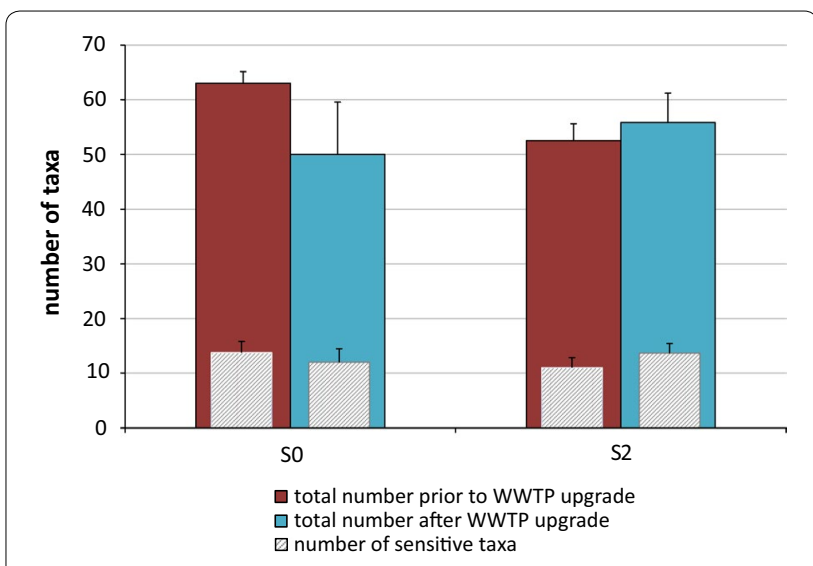

Fig. 11 Number of taxa (red, blue) and sensitive taxa (shaded) before and after the WWTP upgrade. Mean values and standard deviations are shown. Samples were taken two times per year in spring and autumn before (red and black shaded in red; spring and autumn $2011,2012,2013)$ and after (blue and black shaded in blue; spring and autumn 2014, 2015, 2016) the WWTP upgrade. S0: reference site upstream of the effluent; 52 : directly downstream of the effluent.

Definition of sensitive taxa according to assessment procedures from Austria $[56,57]$. The assessment of the macrobenthos community is generally based on $[58,59]$

This project aimed to survey the efficiency of advanced wastewater treatment for (1) the reduction in micropollutants and bacteria in the effluent and (2) the possible improvement in wildlife health in WWTP-connected rivers. To the best of our knowledge, SchussenAktivplus is the first project worldwide that has addressed this topic using a holistic approach, simultaneously recording the 
presence, concentrations, and impact of chemical compounds and opportunistic pathogens, both in the effluent of the WWTP and in the connected river. By means of a simultaneous exposure and effect characterisation, it therefore meets the demands for a holistic and more realistic monitoring of water pollution as also demanded by Brack et al. [60] for the EU Water Framework Directive.

Overall, the study highlights numerous positive effects of an additional powdered activated carbon stage within 3 years after its installation, both on the exposure and the effect side. After the WWTP expansion, concentrations of micropollutants were considerably lower in the WWTP effluent, the receiving water course, and in biota samples. The elimination rates for micropollutants were substance specific, with moderately degradable substances, like carbamazepine, metoprolol, $1 H$-benzotriazole, or diclofenac, being reduced by over $80 \%$ with additional treatment by powdered activated carbon. Furthermore, the loads of PFOS in water and fish tissues were significantly reduced. Therefore, our study supports earlier investigations of the efficiency of advanced wastewater treatment for the reduction in micropollutants from effluents [61-64]. In addition to the reduction in micropollutant concentrations, the absolute concentrations of non-resistant and resistant bacteria in the effluent were also significantly lower after the upgrade. In comparison with the already pre-existing secondary clarification step, we observed an $87 \%$ reduction in E. coli and a $90.5 \%$ reduction in intestinal enterococci concentrations. A previous study by Margot et al. [65] reported much lower elimination rates of $11 \%$ for $E$. coli and $78 \%$ for intestinal enterococci. However, the elimination of pathogens by powdered activated carbon is determined by the adsorption rate and depends on various factors, including pore size of the activated carbon, the $\mathrm{pH}$, or different characteristics of bacterial cells, as discussed in quartz sand by Foppen et al. [66].

The combination of laboratory, semi-field, and field investigations with different fish species and gammarids, as well as an examination of the macrozoobenthic community in the receiving stream, allowed the detection of positive effects at different levels of biological organisation associated with the WWTP upgrade. This approach, addressing responses from prey to predators and from the (sub)individual to the community level simultaneously in a single study, is exceptional for this type of project. In accordance with the pronounced reduction in micropollutant concentrations in effluent and surface water samples, there was a significant decrease in genotoxic, oestrogenic, embryotoxic, and dioxin-like potentials in these samples, as indicated by in vitro and in vivo biotests conducted in the laboratory. Concomitantly, a reduction in symptoms in exposed and indigenous fish and gammarids was detected. Hence, significant reductions in micronuclei frequencies, biotransformation rates, and histopathological alterations prevailing in actively exposed and feral fish, and positive changes with respect to fecundity indices in female gammarids living downstream of the WWTP were found. Even though our study may be rather unique in complexity, individual effects of advanced wastewater treatment have been observed in previous studies. Thus, Stalter et al. [67] and Magdeburg et al. [68] observed a reduction in genotoxic and endocrine effects in biotests conducted with water samples treated with powdered activated carbon. In line with our findings, Beijer et al. [69] detected reduced biotransformation levels in fish exposed to effluent from a WWTP equipped with activated carbon treatment.

The pronounced increase in pollution-sensitive macrozoobenthic species and a decrease in the saprobity downstream of the inlet of treated wastewater can plausibly be correlated with the reduced micropollutant concentrations. Local fishermen even reported higher catching numbers of various fish species at sites downstream of the WWTP after its upgrade.

Despite the fact that positive effects could be detected for many biotests and biomarkers after the WWTP upgrade at downstream sites, for some investigated parameters such as the cholinesterase activity or stress proteins in fish livers, improvements were either also observed at the reference sites, or were not observed at all. In these cases, a possible impact of the WWTP cannot be distinguished from seasonal or annual influences on the respective biomarkers. The high degree of complexity in a field system is also reflected by the output of the multivariate analyses on cage-exposed fish, where the proportion of explainable variation was comparably low.

An improvement in animal health and community integrity in the Schussen River was evident already 3 years after the WWTP upgrade. Applying the weightof-evidence approach, the association between the WWTP upgrade, the observed reduction in micropollutant concentrations in effluent, surface water and biota samples, and the health improvement at various levels of biological organisation undoubtedly reflects causality. Due to the project design, which includes (1) a vast number of methods to characterise exposure and effects in parallel, (2) experiments in a temporal and a spatial gradient, and (3) different experimental approaches with increasing field relevance, several causation criteria of Bradford Hill (i.e. strength of association, coherence, consistency, temporality, and plausibility) are met. Therefore, solid evidence for a causal relationship between the establishment of additional activated carbon-based wastewater treatment and an improvement in biota and ecosystem health within a rather short period of time is 
provided (methodology described by Triebskorn et al. [70], and Swaen and van Amelsvoort [71]).

Long-term benefits of advanced wastewater treatment based on powdered activated carbon for aquatic ecosystems have already been described by Thellmann et al. [47] and Triebskorn et al. [72]. These studies focussed on another central European river (Schmiecha), which had been reported to be highly polluted by wastewater originating from textile industry in the second half of the twentieth century. To reduce this contamination, the connected WWTP was equipped with an additional powdered activated carbon stage in the 1990s. More than 20 years later, the situation has considerably changed as macro- and micropollutant concentrations substantially declined [64]. A further study revealed a high integrity of fish health and of the entire ecosystem in this stream today [72].

Although in Southern Germany, the first WWTP upgrades were characterised by the addition of powdered activated carbon stages, and although the present study also focuses on this type of upgrade, powdered activated carbon is not the only option for advanced wastewater treatment. Other technologies, such as membrane filtration or ozonation in combination with granulated carbon or sand filters, are also at our disposal today and can equally be realised on large scale. In practice, making a decision on the most suitable technology depends on several criteria such as the already existing infrastructure, the composition of the wastewater, or the usage of the receiving water body (e.g. for swimming, fishing, or abstraction of drinking water). Taking these factors into account, the pros and cons of the potential technologies have to be weighed against each other, as they concern differing efficiencies and specificities to reduce micropollutants and bacteria, different expenses (also associated with energy requirements and waste disposal), and other aspects related to environmental sustainability $[25,73]$.

Regardless of the selected technology, however, an improved wastewater treatment has to be considered as one important key stone measure to abate the risk posed by chemical mixtures for aquatic wildlife. In combination with improved monitoring and assessment strategies, as, for example, recently proposed by the SOLUTION project [74-76] it will support the reduction in chemical and microbiological burdens in aquatic ecosystems and contribute to the achievement of a good-or at least improvedquality status of European water bodies latest by 2027 as demanded by the European Water Framework Directive.

\section{Conclusions}

In summary, the explicit advancement of the present study lies in (a) providing evidence for causality between a WWTP upgrade by powdered activated carbon and ecosystem improvement and (b) showing the promptness of positive ecological changes in response to such action. The outcome of this study urgently advocates an investment in further wastewater treatment as a basis for decreasing the release of micropollutants and both resistant and non-resistant bacteria into receiving water bodies and, as a consequence, to sustainably protect river ecosystem health and drinking water resources for mankind in the future.

\section{Abbreviations}

ACE: acesulfame; BTZ: 1 H-benzotriazole; CBZ: carbamazepine; CFU: colonyforming units; DCF: diclofenac; DiOH-CBZ: 10,11-dihydro-10,11-dihydroxycarbamazepine; E. coll: Escherichia coli; ECD agar: Escherichia coli direct agar; ELS: fish early life stage test; EROD: ethoxyresorufin-O-deethylase; FET: fish embryo acute toxicity test; hsp: heat shock protein; LOQ: limit of quantification; MTP: metoprolol; PCA: principal component analysis; PFBA: perfluorobutanoate; PFOA: perfluorooctanoate; PFOS: perfluorooctanesulfonate; RDA: redundancy analysis; SAK254: spectral absorption coefficient at $254 \mathrm{~nm}$, a sum parameter giving information about the organic load in water samples; SMX: sulfomethoxazole; SOB: storm water overflow basin; TCPP: tris(2-chloropropyl) phosphate; WWTP: wastewater treatment plant; Y(A)ES: yeast (anti-) oestrogen screen; Y(A)AS: yeast (anti-) androgen screen; 4-FAA: 4-formylaminoantipyrine; 4-AAA: 4-acetaminoantipyrine; 4- and 5-MBTZ: 4- and 5-methylbenzotriazole.

\section{Acknowledgements}

We are highly grateful to Hans-Joachim Vogel [formerly Regional Commission (RP) Tübingen] and to Gerd Schroeder and Hans Güde (ISF Langenargen) for their invaluable support and engagement. For intense support with the data analysis, our thanks go to Merav Seifan (formerly Plant Ecology group, University of Tübingen). For data collection, the organisation and realisation of sampling, as well as for contributing to management of the project, we particularly thank Raphaela Osterauer, Stefanie Krais, Anja Henneberg, and Diana Maier (all Animal Physiological Ecology group, University of Tübingen). We also thank Stefanie Heß for isolation of staphylococci and antibiotic susceptibility testing of bacterial isolates at the University of Applied Science Emden/Leer. Additional thanks go to Brigitte Engesser and her fishermen (Institute of Lake Research, Langenargen) for the fishing events and to Michael Weyhmüller (BBW Achberg) for maintaining the two bypass mesocosms. We are also indebted to Klaus Jedele and Michael Müller (Jedele \& Partner) for their support in all aspects of engineering. We acknowledge support by Open Access Publishing Fund of University of Tübingen.

\section{Authors' contributions}

RT coordinated and managed the project, supervised all studies with fish and invertebrates, and wrote the first draft of this manuscript; HH and HRK assisted in coordination and management of the project; SW, PT, and KP were responsible for biomarker data in fish and gammarids and for fish embryo tests; SS conducted the multivariate statistical analyses; MS and FS were responsible for the chemical analyses; LB, SG, and JO investigated dioxin-like and hormonal activity; BK studied oestrogenicity with the E-screen assay; CG and FL were responsible for the microbiological studies; KW analysed the macrozoobenthos community; SW intensely revised the manuscript; and all other authors were also involved in its revision. All authors read and approved the final manuscript.

\section{Funding}

The project SchussenAktivplus was funded by the Federal Ministry for Education and Research (BMBF) and co-funded by the Ministry of Environment Baden-Württemberg. In addition, Jedele \& Partner GmbH, Ökonsult GbR, the city of Ravensburg, AZV Mariatal, and AV Unteres Schussental contributed financially to the project. SchussenAktivplus was connected to the BMBF action plan "Sustainable water management ( $\mathrm{NaWaM}$ )" and is integrated in the BMBF frame programme "Research for sustainable development FONA". Contract period: 1/2012 to 12/2014; Funding Number: 02WRS1281A-L. 


\section{Availability of data and materials}

Materials, data, and associated protocols will promptly be made available to readers without undue qualifications in material transfer agreements.

\section{Ethical approval}

All experiments were carried out in strict accordance with the German law on animal experiments. Permission was given by the animal welfare authority of the Regional Council Tübingen (Regierungspräsidium Tübingen), and permit numbers for experiments with trout are ZO 1/09, ZP 1/12, and ZO $1 / 15$. Sampling of chub and spirlin was reported under document number AZ 35/9185.82-2 on January 12,2015. Fish were anaesthetised and euthanised with MS-222 (tricaine mesylate), and handling and caging stress were minimised.

\section{Consent for publication}

Not applicable.

\section{Competing interests}

The authors declare that they have no competing interests.

\section{Author details}

${ }^{1}$ Animal Physiological Ecology, University of Tübingen, Tübingen, Germany.

2 Present Address: German Environment Agency (UBA), Section IV 2.2,

Dessau-Roßlau, Germany. ${ }^{3}$ Present Address: Ibacon GmbH, Roßdorf, Germany.

${ }^{4}$ Steinbeis Transfer Centre Ecotoxicology and Ecophysiology, Rottenburg, Germany. ${ }^{5}$ RECETOX, Faculty of Science, Masaryk University, Brno, Czech Republic ${ }^{6}$ Faculty of Technology, Microbiology-Biotechnology, University of Applied Science Emden/Leer, Emden, Germany. ${ }^{7}$ Department Aquatic Ecotoxicology, Goethe University, Frankfurt Am Main, Germany. ${ }^{8}$ Present Address: DECHEMA e.V, Frankfurt Am Main, Germany. ${ }^{9}$ LUBW, ISF, Baden-Württemberg State Institute for the Environment, Institute for Lake Research, Langenargen, Germany. ${ }^{10}$ Institute for Sanitary Engineering, Water Quality and Solid Waste Management, University of Stuttgart, Stuttgart, Germany. ${ }^{11}$ TZW: Water Technology Centre Karlsruhe, Karlsruhe, Germany. ${ }^{12}$ GÖL Water Ecology Laboratory Starzach, Starzach, Germany.

Received: 9 August 2019 Accepted: 19 October 2019

Published online: 06 November 2019

\section{References}

1. Jekel M, Ruhl A, Meinel F, Zietzschmann F, Lima S, Baur N, Wenzel M, Gnirß R, Sperlich A, Dünnbier U, Böckelmann U, Hummelt D, van Baar P, Wode F, Petersohn D, Grummt T, Eckhardt A, Schulz W, Heermann A, Reemtsma T, Seiwert B, Schlittenbauer L, Lesjean B, Miehe U, Remy C, Stapf M, Mutz D (2013) Anthropogenic organic micro-pollutants and pathogens in the urban water cycle: assessment, barriers and risk communication (ASKURIS). Environ Sci Eur 25(1):20. https://doi. org/10.1186/2190-4715-25-20

2. Brillard J, Dupont CMS, Berge $O$, Dargaignaratz C, Oriol-Gagnier S, Doussan C, Broussolle V, Gillon M, Clavel T, Bérard A (2015) The water cycle, a potential source of the bacterial pathogen Bacillus cereus. Biomed Res Int 2015:356928. https://doi.org/10.1155/2015/356928

3. Bu Q, Luo Q, Wang D, Rao K, Wang Z, Yu G (2015) Screening for over 1000 organic micropollutants in surface water and sediments in the Liaohe River watershed. Chemosphere 138:519-525. https://doi.org/10.1016/j. chemosphere.2015.07.013

4. Exner MST (2015) RiSKWa-Statuspapier Bewertungskonzepte der Mikrobiologie mit den Schwerpunkten neue Krankheitserreger und Antibiotikaresistenzen. DECHEMA e.V, Frankfurt am Main

5. Kim M-K, Zoh K-D (2016) Occurrence and removals of micropollutants in water environment. Environ Eng Res 21(4):319-332. https://doi. org/10.4491/eer.2016.115

6. Exner M, Bhattacharya S, Christiansen B, Gebel J, Goroncy-Bermes P, Hartemann P, Heeg P, Ilschner C, Kramer A, Larson E, Merkens W, Mielke M, Oltmanns P, Ross B, Rotter M, Schmithausen RM, Sonntag HG, Trautmann M (2017) Antibiotic resistance: what is so special about multidrug-resistant gram-negative bacteria? GMS Hyg Infect Control 12:Doc05. https:// doi.org/10.3205/dgkh000290

7. Heß S, Berendonk TU, Kneis D (2018) Antibiotic resistant bacteria and resistance genes in the bottom sediment of a small stream and the potential impact of remobilization. FEMS Microbiol Ecol. https://doi. org/10.1093/femsec/fiy128

8. Maisa A, Brockmann A, Renken F, Lück C, Pleischl S, Exner M, DanielsHaardt I, Jurke A (2015) Epidemiological investigation and case-control study: a Legionnaires' disease outbreak associated with cooling towers in Warstein, Germany, August-September 2013. Euro surveill. https://doi. org/10.2807/1560-7917.es.2015.20.46.30064

9. Schang C, Henry R, Kolotelo PA, Prosser T, Crosbie N, Grant T, Cottam D, O'Brien P, Coutts S, Deletic A, McCarthy DT (2016) Evaluation of techniques for measuring microbial hazards in bathing waters: a comparative study. PLoS ONE 11(5):e0155848. https://doi.org/10.1371/journ al.pone.0155848

10. World Health Organization (2018) Antimicrobial resistance. http://www who.int/mediacentre/factsheets/fs194/en/. Accessed 18 Mar 2019

11. Benotti MJ, Trenholm RA, Vanderford BJ, Holady JC, Stanford BD, Snyder SA (2009) Pharmaceuticals and endocrine disrupting compounds in U.S. drinking water. Environ Sci Technol 43(3):597-603. https://doi. org/10.1021/es801845a

12. Cotruvo JA (1985) Organic micropollutants in drinking water: an overview. Sci Total Environ 47:7-26. https://doi.org/10.1016/00489697(85)90316-x

13. Mompelat $S$, Le Bot B, Thomas $O$ (2009) Occurrence and fate of pharmaceutical products and by-products, from resource to drinking water. Environ Int 35(5):803-814. https://doi.org/10.1016/j.envint.2008.10.008

14. Zylka-Menhorn V (2018) Arzneimittelrückstände im Wasser: Vermeidung und Elimination. Dtsch Arztebl 115(22):1054-1056

15. Gimeno S, Komen H, Jobling S, Sumpter J, Bowmer T (1998) Demasculinisation of sexually mature male common carp, Cyprinus carpio, exposed to 4-tert-pentylphenol during spermatogenesis. Aquat Toxicol 43(2-3):93109. https://doi.org/10.1016/S0166-445X(98)00060-5

16. Brodin T, Fick J, Jonsson M, Klaminder J (2013) Dilute concentrations of a psychiatric drug alter behavior of fish from natural populations. Science 339(6121):814-815. https://doi.org/10.1126/science.1226850

17. Brack W, Dulio V, Ågerstrand M, Allan I, Altenburger R, Brinkmann M, Bunke D, Burgess RM, Cousins I, Escher BI, Hernández FJ, Hewitt LM, Hilscherová K, Hollender J, Hollert H, Kase R, Klauer B, Lindim C, Herráez DL, Miège C, Munthe J, O'Toole S, Posthuma L, Rüdel H, Schäfer RB, Sengl $M$, Smedes F, van de Meent $D$, van den Brink PJ, van Gils J, van Wezel AP, Vethaak AD, Vermeirssen E, Ohe PC, Vrana B (2017) Towards the review of the European Union Water Framework Directive: recommendations for more efficient assessment and management of chemical contamination in European surface water resources. Sci Total Environ 576:720-737. https ://doi.org/10.1016/j.scitotenv.2016.10.104

18. Davison A, Howard G, Stevens M, Callan P, Fewtrell L, Deere D, Bartram J (2009) Water safety plans - managing drinking-water quality from catchment to consumer (No. WHO/SDE/WSH/05.06). World Health Organization, Geneva

19. Brack W, Ait-Aissa S, Altenburger R, Cousins I, Dulio V, Escher B, Focks A, Ginebreda A, Hering D, Hilscherová K, Hollender J, Hollert H, Kortenkamp A, de Alda ML, Posthuma L, Schymanski E, Segner H, Slobodnik J (2019) Let us empower the WFD to prevent risks of chemical pollution in European rivers and lakes. Environ Sci Eur 31(1):47. https://doi.org/10.1186/ s12302-019-0228-7

20. Kienle C, Kase R, Werner I (2011) Evaluation of bioassays and wastewater quality: in vitro and in vivo bioassays for the performance review in the Project "Strategy MicroPoll". Swiss Centre for Applied Ecotoxicology, Eawag-EPFL, Duebendorf

21. Howe CA, Butterworth J, Smout IK, Duffy AM, Vairavamoorthy K (2011) Sustainable water management in the city of the future-findings from the SWITCH project 2006-2011. http://www.switchurbanwater.eu/outpu ts/pdfs/SWITCH___Final_Report.pdf. Accessed 18 Mar 2019

22. Lyko S, Nafo I, Evenblij H, Benetto E, Cornelissen A, Igos E, Klepiszewski K, Venditti S, Kovalova L, McArdell C (2012) Pharmaceutical input and elimination from local sources: final report of the European co-operation project PILLS. Gelsenkirchen, Germany

23. TrackT (2017) Risk management of emerging compounds and pathogens in the water cycle-handbook of good practice. DECHEMA e.V, Frankfurt am Main

24. Triebskorn R, Blaha L, Engesser B, Güde H, Henneberg A, Hetzenauer $H$, Köhler H-R, Krais S, Kuch B, Maier D, Oehlmann J, Peschke K, Rault M, Rey P, Richter D, Sacher F, Suchail S, Thellmann P, Weyhmüller M, Wurm K, and 
VH-J (2013) SchussenAktiv - Eine Modellstudie zur Effizienz der Reduktion der Gehalte an anthropogenen Spurenstoffen durch Aktivkohle in Kläranlagen: Expositions- und Effektmonitoring vor Inbetriebnahme der Adsorptionsstufe auf der Kläranlage Langwiese des AZV Mariatal, Ravensburg. Korrespondenz Wasserwirtschaft 8:427-436

25. Triebskorn R (ed) (2017) Weitergehende Abwasserreinigung: ein wirksames und bezahlbares Instrument zur Verminderung von Spurenstoffen und Keimen im Wasserkreislauf: gemeinsamer Schlussbericht der vom Bundesministerium für Bildung und Forschung sowie vom Ministerium für Umwelt, Klima und Energiewirtschaft Baden-Württemberg geförderten Projekte SchussenAktiv, SchussenAktivplus und SchussenAktivplus+. Universitätsbibliothek Tübingen, Tübingen, Germany. https:// doi.org/10.15496/publikation-15721

26. Maier D, Benisek M, Blaha L, Dondero F, Giesy JP, Köhler H-R, Richter D, Scheurer M, Triebskorn R (2016) Reduction of dioxin-like toxicity in effluents by additional wastewater treatment and related effects in fish. Ecotoxicol Environ Saf 132:47-58. https://doi.org/10.1016/j.ecoen v.2016.04.036

27. Peschke K, Geburzi J, Köhler H-R, Wurm K, Triebskorn R (2014) Invertebrates as indicators for chemical stress in sewage-influenced stream systems: toxic and endocrine effects in gammarids and reactions at the community level in two tributaries of Lake Constance, Schussen and Argen. Ecotoxicol Environ Saf 106:115-125. https://doi.org/10.1016/j. ecoenv.2014.04.011

28. Triebskorn R, Hetzenauer H (2012) Micropollutants in three tributaries of Lake Constance, Argen, Schussen and Seefelder Aach-a literature review. Environ Sci Eur 24(1):1-24

29. Thellmann P, Greiner-Perth $K$, Jacob S, Knoll M, Schäfer M, Stängle $M$, Ziegler M, Scheurer M, Köhler HR, Triebskorn R (2017) Does waste water treatment plant upgrading with powdered activated carbon result in reduced water and sediment toxicity of the receiving stream. Int Water Wastewater Treat. https://doi.org/10.16966/2381-5299.141

30. Wilhelm S, Henneberg A, Köhler H-R, Rault M, Richter D, Scheurer M, Suchail S, Triebskorn R (2017) Does wastewater treatment plant upgrading with activated carbon result in an improvement of fish health? Aquat Toxicol 192:184-197. https://doi.org/10.1016/j.aquatox.2017.09.017

31. Henneberg A, Triebskorn R (2015) Efficiency of advanced wastewater treatment technologies for the reduction of hormonal activity in effluents and connected surface water bodies by means of vitellogenin analyses in rainbow trout (Oncorhynchus mykiss) and brown trout (Salmo trutta f. fario). Environ Sci Eur 27(1):22. https://doi.org/10.1186/s1230 2-015-0056-3

32. Maier D, Blaha L, Giesy JP, Henneberg A, Köhler H-R, Kuch B, Osterauer R, Peschke K, Richter D, Scheurer M, Triebskorn R (2015) Biological plausibility as a tool to associate analytical data for micropollutants and effect potentials in wastewater, surface water, and sediments with effects in fishes. Water Res 72:127-144. https://doi.org/10.1016/j.watres.2014.08.050

33. E.U. Council (2006) Council Directive 2006/88/EC of 24 October 2006 on animal health requirements for aquaculture animals and products thereof, and on the prevention and control of certain diseases in aquatic animals. Off J Eur Comm L 328:14-56

34. Vincze K, Scheil V, Kuch B, Köhler H-R, Triebskorn R (2015) Impact of wastewater on fish health: a case study at the Neckar River (Southern Germany) using biomarkers in caged brown trout as assessment tools. Environ Sci Pollut Res Int 22(15):11822-11839. https://doi.org/10.1007/ s11356-015-4398-6

35. Scheurer M, Heß S, Lüddeke F, Sacher F, Güde H, Löffler H, Gallert C (2015) Removal of micropollutants, facultative pathogenic and antibiotic resistant bacteria in a full-scale retention soil filter receiving combined sewer overflow. Environ Sci 17(1):186-196. https://doi.org/10.1039/c4em00494a

36. Heß S, Lüddeke F, Gallert C (2016) Concentration of facultative pathogenic bacteria and antibiotic resistance genes during sewage treatment and in receiving rivers. Water Sci Technol 74(8):1753-1763. https://doi. org/10.2166/wst.2016.304

37. Giebner S, Ostermann S, Straskraba S, Oetken M, Oehlmann J, Wagner M (2018) Effectivity of advanced wastewater treatment: reduction of in vitro endocrine activity and mutagenicity but not of in vivo reproductive toxicity. Environ Sci Pollut Res Int 25(5):3965-3976. https://doi.org/10.1007/ s11356-016-7540-1

38. White PA, Rasmussen JB, Blaise C (1996) A semi-automated, microplate version of the SOS Chromotest for the analysis of complex environmental extracts. Mutat Res 360(1):51-74. https://doi.org/10.1016/S0165 $-1161(96) 90237-X$

39. Garrison PM, Tullis K, Aarts JM, Brouwer A, Giesy JP, Denison MS (1996) Species-specific recombinant cell lines as bioassay systems for the detection of 2,3,7,8-tetrachlorodibenzo-p-dioxin-like chemicals. Fundam Appl Toxicol 30(2):194-203

40. Stalter D, Magdeburg A, Wagner M, Oehlmann J (2011) Ozonation and activated carbon treatment of sewage effluents: removal of endocrine activity and cytotoxicity. Water Res 45(3):1015-1024. https://doi. org/10.1016/j.watres.2010.10.008

41. Lange C, Kuch B, Metzger JW (2014) Estrogenic activity of constituents of underarm deodorants determined by E-Screen assay. Chemosphere 108:101-106. https://doi.org/10.1016/j.chemosphere.2014.02.082

42. U. S. EPA (2011) Estrogen receptor transcriptional activation (human cell line-HeLa-9903). Standard Evaluation Procedure (SEP)

43. Henneberg A, Bender K, Blaha L, Giebner S, Kuch B, Köhler H-R, Maier D, Oehlmann J, Richter D, Scheurer M, Schulte-Oehlmann U, Sieratowicz A, Ziebart S, Triebskorn R (2014) Are in vitro methods for the detection of endocrine potentials in the aquatic environment predictive for in vivo effects? Outcomes of the projects SchussenAktiv and SchussenAktivplus in the Lake Constance Area, Germany. PLoS ONE 9(6):e98307. https://doi. org/10.1371/journal.pone.0098307

44. Wilson VS, Bobseine K, Lambright CR, Gray LE (2002) A novel cell line, MDA-kb2, that stably expresses an androgen- and glucocorticoidresponsive reporter for the detection of hormone receptor agonists and antagonists. Toxicol Sci 66(1):69-81

45. OECD (2006) Test No. 221: Lemna sp. growth inhibition test. OECD guidelines for the testing of chemicals, section 2. https://doi. org/10.1787/9789264016194-en

46. OECD (2013) Test No. 236: Fish embryo acute toxicity (FET) test. OECD guidelines for the testing of chemicals, section 2. https://doi. org/10.1787/9789264203709-en

47. Thellmann P, Köhler H-R, Rößler A, Scheurer M, Schwarz S, Vogel H-J, Triebskorn R (2015) Fish embryo tests with Danio rerio as a tool to evaluate surface water and sediment quality in rivers influenced by wastewater treatment plants using different treatment technologies. Environ Sci Pollut Res Int 22(21):16405-16416. https://doi.org/10.1007/s1135 6-014-3785-8

48. OECD (2007) Test No. 225: sediment-water Lumbriculus toxicity test using spiked sediment. OECD guidelines for the testing of chemicals, section 2. https://doi.org/10.1787/9789264067356-en

49. OECD (2016) Test No. 242: Potamopyrgus antipodarum reproduction test. OECD guidelines for the testing of chemicals, section 2. https://doi. org/10.1787/9789264264311-en

50. Rault M, Collange B, Mazzia C, Capowiez Y (2008) Dynamics of acetylcholinesterase activity recovery in two earthworm species following exposure to ethyl-parathion. Soil Biol Biochem 40(12):3086-3091. https:// doi.org/10.1016/j.soilbio.2008.09.010

51. Chanda SM, Mortensen SR, Moser VC, Padilla S (1997) Tissue-specific effects of chlorpyrifos on carboxylesterase and cholinesterase activity in adult rats: an in vitro and in vivo comparison. Toxicol Sci 38(2):148-157. https://doi.org/10.1093/toxsci/38.2.148

52. Luckenbach T, Kilian M, Triebskorn R, Oberemm A (2001) Fish early life stage tests as a tool to assess embryotoxic potentials in small streams. J Aquat Ecosyst Stress Recovery 8:355-370. https://doi. org/10.1023/A:1012976809450

53. Council European (2000) Directive 2000/60/EC of the European Parliament and of the Council of 23 October 2000 establishing a framework for Community action in the field of water policy. Off J 22(12):2000

54. Peschke K, Capowiez Y, Köhler HR, Wurm K, Triebskorn R (2019) Impact of a wastewater treatment plant upgrade on amphipods and other macroinvertebrates: individual and community responses. Fron Environ Sci. https://doi.org/10.3389/fenvs.2019.00064

55. OECD (2013) Test No. 236: fish embryo acute toxicity (FET) test. https:// doi.org/10.1787/9789264203709-en

56. Wilhelm S, Jacob S, Ziegler M, Köhler H-R, Triebskorn R (2018) Influence of different wastewater treatment technologies on genotoxicity and dioxinlike toxicity in effluent-exposed fish. Environ Sci Eur 30(1):619. https://doi. org/10.1186/s12302-018-0154-0

57. Peschke K, Burmester J, Hermann M, Köhler H-R, Reitter K, Scheurer M, Wurm K, and Triebskorn R (2016) Reaktionen von Flohkrebsen und 
Makrozoobenthos auf die Nachrüstung einer Kläranlage mit einer Pulveraktivkohlestufe. gwf - Wasser/Abwasser 157(4):370-379

58. OfenböckT, Moog O, Hartmann A, Stubauer I (2010) Leitfaden zur Erhebung der Biologischen Qualitätselemente, Teil A2 - Makrozoobenthos" herausgegeben vom Bundesministerium für Land- und Forstwirtschaft. Umwelt und Wasserwirtschaft, Wien

59. Meier C, Böhmer J, Biss R, Feld C, Haase P, Lorenz A, Rawer-Jist C, Rolauffs P, Schindehütte K, Schöll F, Sundermann A, Zenker A, and Hering D (2006) Weiterentwicklung und Anpassung des nationalen Bewertungssystems für Makrozoobenthos an neue internationale Vorgaben. http://www.flies sgewaesser-bewertung.de/downloads/abschlussbericht_20060331.pdf (download october 26, 2019)

60. Brack W, Escher Bl, Müller E, Schmitt-Jansen M, Schulze T, Slobodnik J, Hollert H (2018) Towards a holistic and solution-oriented monitoring of chemical status of European water bodies: how to support the EU strategy for a non-toxic environment? Environ Sci Eur 30(1):33. https:// doi.org/10.1186/s12302-018-0161-1

61. Hansen MC, Børresen MH, Schlabach M, Cornelissen G (2010) Sorption of perfluorinated compounds from contaminated water to activated carbon. J Soils Sed 10(2):179-185. https://doi.org/10.1007/s1136 8-009-0172-z

62. Margot J, Rossi L, Barry DA, Holliger C (2015) A review of the fate of micropollutants in wastewater treatment plants. WIREs Water 2(5):457-487. https://doi.org/10.1002/wat2.1090

63. Meinel F, Zietzschmann F, Ruhl AS, Sperlich A, Jekel M (2016) The benefits of powdered activated carbon recirculation for micropollutant removal in advanced wastewater treatment. Water Res 91:97-103. https://doi. org/10.1016/j.watres.2016.01.009

64. Vogel H-J, Baur S, Triebskorn R, Rößler A, and Metzger S (2014) Die Kläranlage Albstadt-Ebingen: 20 Jahre Pulveraktivkohleeinsatz im Vollstrom. Abwassertechnische Besonderheiten und Effizienz für die Elimination von Spurenstoffen. Korrespondenz Abwasser, Abfall 61. https://doi. org/10.3242/kae2014.10.005

65. Margot J, Kienle C, Magnet A, Weil M, Rossi L, Alencastro LF, Abegglen C, Thonney D, Chèvre N, Schärer M, Barry DA (2013) Treatment of micropollutants in municipal wastewater: ozone or powdered activated carbon? Sci Total Environ 461-462:480-498. https://doi.org/10.1016/j.scito tenv.2013.05.034

66. Foppen JW, Lutterodt G, Röling WFM, Uhlenbrook S (2010) Towards understanding inter-strain attachment variations of Escherichia coli during transport in saturated quartz sand. Water Res 44(4):1202-1212. https ://doi.org/10.1016/j.watres.2009.08.034

67. Stalter D, Magdeburg A, Oehlmann J (2010) Comparative toxicity assessment of ozone and activated carbon treated sewage effluents using an in vivo test battery. Water Res 44(8):2610-2620. https://doi.org/10.1016/j. watres.2010.01.023

68. Magdeburg A, Stalter D, Schlüsener M, Ternes T, Oehlmann J (2014) Evaluating the efficiency of advanced wastewater treatment: target analysis of organic contaminants and (geno-)toxicity assessment tell a different story. Water Res 50:35-47. https://doi.org/10.1016/j.watres.2013.11.041
69. Beijer K, Björlenius B, Shaik S, Lindberg RH, Brunström B, Brandt I (2017) Removal of pharmaceuticals and unspecified contaminants in sewage treatment effluents by activated carbon filtration and ozonation: evaluation using biomarker responses and chemical analysis. Chemosphere 176:342-351. https://doi.org/10.1016/j.chemosphere.2017.02.127

70. Triebskorn R, Adam S, Behrens A, Beier S, Böhmer J, Braunbeck T, Casper H, Dietze U, Gernhöfer M, Honnen W, Köhler H-R, Körner W, Konradt J, Lehmann R, Luckenbach T, Oberemm A, Schwaiger J, Segner H, Strmac M, Schüürmann G, Siligato S, Traunspurger W (2003) Establishing causality between pollution and effects at different levels of biological organization: the VALIMAR project. Hum Ecol Risk Assess 9(1):171-194. https://doi. org/10.1080/713609858

71. Swaen G, van Amelsvoort L (2009) A weight of evidence approach to causal inference. J Clin Epidemiol 62(3):270-277. https://doi. org/10.1016/j.jclinepi.2008.06.013

72. Triebskorn R, Thellmann P, Vogel H-J, and Wurm K (2014) Die Kläranlage Albstadt-Ebingen: Aktivkohlefilterung im Vollstrom seit 1992 - Ein langfristiger Erfolg für die Fischgesundheit und die Gewässerökologie. Korrespondenz Wasserwirtschaft $\mathbf{7}(9)$

73. Eggen RIL, Hollender J, Joss A, Schärer M, Stamm C (2014) Reducing the discharge of micropollutants in the aquatic environment: the benefits of upgrading wastewater treatment plants. Environ Sci Technol 48(14):7683-7689. https://doi.org/10.1021/es500907n

74. BrackW (2019) Solutions for present and future emerging pollutants in land and water resources management. Policy briefs summarizing scientific project results for decision makers. Environ Sci Eur 31:74

75. Carvalho L, Mackay EB, Cardoso AC, Baattrup-Pedersen A, Birk S, Blackstock KL, Borics G, Borja A, Feld CK, Ferreira MT, Globevnik L, Grizzetti B, Hendry S, Hering D, Kelly M, Langaas S, Meissner K, Panagopoulos Y, Penning E, Rouillard J, Sabater S, Schmedtje U, Spears BM, Venohr M, van de Bund W, Solheim AL (2019) Protecting and restoring Europe's waters: an analysis of the future development needs of the water framework directive. Sci Total Environ. 25(658):1228-1238. https://doi.org/10.1016/j. scitotenv.2018.12.255 (Epub 2018 Dec 18)

76. Posthuma L, Backhaus T, Hollender J, Bunke D, Brack W, Müller C, van Gils J, Hollert H, Munthe J, van Wezel A (2019) Exploring the 'solution space' is key: SOLUTIONS recommends an early-stage assessment of options to protect and restore water quality against chemical pollution. Environ Sci Eur 31:73

\section{Publisher's Note}

Springer Nature remains neutral with regard to jurisdictional claims in published maps and institutional affiliations.

\section{Submit your manuscript to a SpringerOpen ${ }^{\circ}$ journal and benefit from:}

- Convenient online submission

- Rigorous peer review

- Open access: articles freely available online

- High visibility within the field

- Retaining the copyright to your article

Submit your next manuscript at $\boldsymbol{\nabla}$ springeropen.com 